\title{
ACCIDENTS WITH BIOLOGICAL MATERIAL AND IMMUNIZATION AGAINST HEPATITIS B AMONG STUDENTS FROM THE HEALTH AREA
}

\author{
Elucir Gir ${ }^{1}$ \\ Jeniffer Caffer Netto ${ }^{2}$ \\ Silmara Elaine Malaguti ${ }^{3}$ \\ Silvia Rita Marin da Silva Canini ${ }^{1}$ \\ Miyeko Hayashida ${ }^{4}$ \\ Alcyone Artioli Machado 5
}

Gir E, Caffer Netto J, Malaguti SE, Canini SRMS, Hayashida M, Machado AA. Accidents with biological material and immunization against Hepatitis B among students from the health area. Rev Latino-am Enfermagem 2008 maio-junho; 16(3):401-6.

Undergraduate students from the health area often handle piercing-cutting instruments in their academic activities, which exposes them to the risk of contracting infections. This study aimed to analyze accidents with biological material among these students. Out of 170 accidents registered, 83 (48.8\%) occurred with Dentistry students, 69 (40.6\%) with Medical students, 11 (6.5\%) with Nursing students and in 06 (3.5\%) of the cases there was no such information in the files. Most accidents, 106 (62.4\%), occurred with students from private schools and $55(32.3 \%)$ with those from public schools. Percutaneous accidents occurred in 133 (78.2\%) exposures and there was immediate search for specialized health care in only 38 (21.3\%) accidents. In 127 (74.7\%) accidents, the immunization schedule against hepatitis $B$ was complete. Therefore, schools need to offer courses and specific class subjects regarding biosafety measures, including aspects related to immunization, especially the vaccine against hepatitis $B$.

DESCRIPTORS: occupational risks; students, health occupations; exposure to biological agents; hepatitis B

\section{ACCIDENTE CON MATERIAL BIOLÓGICO Y LA VACUNACIÓN CONTRA LA HEPATITIS B EN ESTUDIANTES DEL ÁREA DE LA SALUD}

La manipulación de instrumentos punzo cortantes por estudiantes del área de la salud es frecuente en la actividad académica, lo que los expone al riesgo de adquirir infecciones. Este estudio tuvo como objetivo analizar los accidentes con material biológico ocurridos en alumnos del área de la salud. De los 170 accidentes registrados, 83 (48,8\%) ocurrieron con alumnos del curso de Odontología, 69 (40,6\%) de Medicina, 11 (6,5\%) de Enfermería y en 06 (3,5\%) no había información en la ficha de atención. La mayoría, 106 (62,4\%), ocurrió con alumnos de escuelas privadas y 55 (32,3\%) de públicas. Los accidentes percutáneos ocurrieron en 133 $(78,2 \%)$ exposiciones y en 38 (21,3\%) accidentes la búsqueda por atención especializada fue inmediata. En 127 (74,7\%) accidentes el esquema de vacunas contra hepatitis B estaba completo. Así es imprescindible que las escuelas ofrezcan cursos y/o disciplinas específicas sobre medidas de bioseguridad incluyendo aspectos relacionados a campañas de vacunación y en especial la vacuna contra hepatitis $B$.

DESCRIPTORES: riesgos laborales; estudiantes de área de la salud; exposición a agentes biológicos; hepatitis $B$

\section{ACIDENTE COM MATERIAL BIOLÓGICO E VACINAÇÃO CONTRA HEPATITE B ENTRE GRADUANDOS DA ÁREA DA SAÚDE}

O manuseio de instrumentos perfurocortantes por estudantes da área da saúde é freqüente na atividade acadêmica, o que os expõe ao risco de adquirir infecção. Este estudo teve como objetivo analisar os acidentes com material biológico, ocorridos com alunos de graduação da área da saúde. Dos 170 acidentes registrados, $83(48,8 \%)$ ocorreram com alunos do curso de odontologia, 69 (40,6\%) de medicina, 11 (6,5\%) de enfermagem e em 6 (3,5\%) não havia a informação na ficha de atendimento. A maioria (106-62,4\%) ocorreu com alunos de escolas privadas e $55(32,3 \%)$ de escolas públicas. Os acidentes percutâneos ocorreram em 133 (78,2\%) exposições e em apenas 38 (21,3\%) acidentes a procura pelo atendimento especializado foi imediata. Em 127 $(74,7 \%)$ acidentes o esquema vacinal contra hepatite $B$ estava completo. Assim, torna-se imprescindível que as escolas ofereçam cursos e/ou disciplinas específicas sobre medidas de biossegurança, incluindo aspectos relacionados à vacinação e em especial à vacina contra hepatite $B$.

DESCRITORES: risco ocupacional; estudantes de ciências da saúde; biossegurança; hepatite B

${ }^{1}$ RN, Full Professor, University of São Paulo at Ribeirão Preto College of Nursing, WHO Collaborating Centre for Nursing Research Development, Brazil, e-mail: egir@eerp.usp.br, canini@eerp; ${ }^{2}$ RN; ${ }^{3}$ RN, M.Sc. in Nursing; ${ }^{4}$ RN, Ph.D. in Nursing, University of São Paulo at Ribeirão Preto College of Nursing, WHO Collaborating Centre for Nursing Research Development, Brazil; ${ }^{5}$ Physician, Faculty, University of São Paulo at Ribeirão Preto Medical School, Brazil 


\section{INTRODUCTION}

A fter recognizing the first case of acquired Human Immunodeficiency Virus (HIV) due to professional $\operatorname{activity}^{(1)}$, and the consequent development of AIDS by a nurse due to accidental piercing with a needle that had the blood of an HIV patient, this subject has become a great challenge to professionals who work in Hospital Infection Control and Occupational Health.

As literature ${ }^{(2-3)}$ indicates, the occupational acquisition of hepatitis B (HBV), hepatitis C (HCV) and HIV viruses by healthcare workers is a real fact. The global scenario(2) of occupational cases of HIV infection among healthcare workers, according to available data in September 1997, comprehended 264 cases. In the United States ${ }^{(3)}$, a recent study registered 57 documented cases of occupational HIV acquisition, $24(42 \%)$ of them involving nurses.

It is worth highlighting that the first case of occupationally acquired AIDS in Brazil was only recognized by the Labor Department in 1999, which affected a nursing assistant who was assisting a venous puncture procedure ${ }^{(4)}$.

Nowadays, there are three cases under investigation as a result of possible occupational transmission ${ }^{(5)}$. Nevertheless, this does not mean there is a low number of seroconversions in Brazil, but it illustrates the lack of effective surveillance, a notification system for this kind of accident and the systematic monitoring of affected professionals.

The risks of exposure to HIV, HBV and $\mathrm{HCV}^{(6)}$ are proportional to the handling of piercing-cutting materials and organic fluids, and the average risk of HCV infection after a percutaneous occupational accident is $1.8 \%$, with a range from 1 to $10 \%$. For $\mathrm{HBV}$, when the source patient is HbeAg positive, the estimated risk is between 6 and $30 \%$, and may reach $40 \%$ if no prophylactic measures are taken; whereas for HIV, when the source patient is positive, this rate ranges from 0.3 to $0.5 \%$, and $0.09 \%$ after exposure of mucous membranes. HIV transmission related to skin exposure has already been documented; however, its risk has not been quantified yet.

Accident prevention measures are divided into pre-exposure and post-exposure measures. Standard precautions are considered some of the main preventive measures aimed at avoiding accidents.

In 1996, the so-called universal precautions were reformulated and renamed standard precautions $^{(7)}$. Even though they maintain the essence of considering risk as universal, it is recommended to extend compliance with protection barriers to all organic fluids, except sweat. The technique of recapping needles with only one of the hands is also admitted as a safe measure.

Immunization is effective as a pre-exposure preventive measure regarding hepatitis prevention; however, there are problems involving health workers' compliance. As a post-exposure preventive measure for HBV(HBIG), specific hyperimmune gammaglobulin is indicated, with $75 \%$ effectiveness in the prevention of this infection ${ }^{(8)}$.

Specific measures for HIV prevention include the recommendation of chemoprophylaxis with antiretroviral agents after occupational exposure. After 1990, three other handbooks were published by the Centers for Disease Control and Prevention ${ }^{(9)}$, and the last publication was released in 2001. Regarding $\mathrm{HCV}$, preventive measures are limited to standard precautions, since there is no other effective measure to reduce its transmission risk until now.

Undergraduate healthcare students develop part of their academic activities in situations that are similar to professional practice, which also put them in danger of exposure to biological material. Data from SINABIO ${ }^{(10)}$ indicate that, among 14,096 accidents with biological material that had been registered in this system from January/1999 to September/2006, 1,067 $(7.6 \%)$ had happened to students. Although there is a growing number of studies about occupational accidents with biological material among healthcare professionals, there are few Brazilian publications about this kind of exposure involving undergraduate students.

Therefore, this study aimed to identify and analyze exposure to potentially contaminated biological material among undergraduate healthcare students in Ribeirão Preto-SP, who sought healthcare at a specialized outpatient clinic of a tertiary hospital and identified their immunization status against hepatitis $\mathrm{B}$.

\section{METHODOLOGY}

This is a descriptive and retrospective study with a quantitative approach about accidents with biological material that happened to undergraduate students, who were treated at a specialized outpatient 
clinic for people involved in this kind of accident at a teaching hospital in the state of São Paulo, Brazil, from January/2003 to May/2005.

Students were identified through a research of accident records, performed by the service responsible for these cases. After the students' identification, the pertinent data were obtained through the observation of the records on a case-by-case basis, and transcribed into a pre-elaborated form.

The collected data included the undergraduates' conditions (age, gender, course, institution of origin, pregnancy); the accident (accident date and time, time spent seeking health care, use of individual protective equipment, material and act causing the exposure, type of exposure, affected area) and the attitude towards the exposure (source patient, immunization against hepatitis $B$, chemoprophylaxis with antiretroviral agents).

Data were inserted in a database, formatted in a Microsoft Excel 2003 spreadsheet and analyzed with Epi Info 2005, version 3.3.2. Results are presented as frequencies and percentages.

The study project was approved by the Research Ethics Committee of the institution where the study was developed.

\section{RESULTS}

In the period from January/2003 to May/2005, 1,125 cases of occupational exposure to biological material were treated at the specialized outpatient clinic, and $170(15.1 \%)$ of these had happened to undergraduate healthcare students.

Regarding the type of educational institution, $106(62.4 \%)$ exposures involved students from a private school, 55 (32.3\%) cases from public schools, and this information could not be identified in 09 (5.3\%) cases. Out of $83(48.8 \%)$ accidents involving Dentistry students, $76(44.7 \%)$ were from private institutions and 5 (2.9\%) from a public institution; Out of 69 (40.6\%) accidents involving Medicine students, 24 $(14.1 \%)$ came from a public institution and 43 (25.3\%) from private courses. In the Nursing course, out of $11(6.5 \%)$ accidents, seven were from public institutions and three from private courses. The only accident $(0.6 \%)$ involving an undergraduate Pharmacy student happened in a private institution (Table 1 ).
Table 1 - Distribution of accidents with biological material among undergraduate health students treated at a specialized outpatient clinic, according to their course and institution of origin. Ribeirão Preto, 2005

\begin{tabular}{lcccccccc}
\hline \multirow{2}{*}{ Course } & \multicolumn{2}{c}{ Private } & \multicolumn{2}{c}{ Public } & \multicolumn{2}{c}{$\begin{array}{c}\text { No } \\
\text { Information }\end{array}$} & \multicolumn{2}{c}{ Total } \\
& No. & $\%$ & No. & $\%$ & No. & $\%$ & No. & $\%$ \\
\hline Dentistry & 76 & 44.7 & 05 & 2.9 & 02 & 1.2 & 83 & 48.8 \\
Medicine & 24 & 14.1 & 43 & 25.3 & 02 & 1.2 & 69 & 40.6 \\
Nursing & 03 & 1.8 & 07 & 4.1 & 01 & 0.6 & 11 & 6.5 \\
Pharmacy & 01 & 0.6 & - & - & - & - & 01 & 0.6 \\
No information & 02 & 1.2 & - & - & 04 & 2.3 & 06 & 3.5 \\
Total & 106 & 62.4 & 55 & 32.3 & 09 & 5.3 & 170 & 100 \\
\hline
\end{tabular}

Regarding gender, women were involved in $100(58.8 \%)$ exposures and men in 70 (41.2\%). No woman was pregnant at the time of the accident. The age of the students varied from 18 to 31 years old, a majority, $147(86.5 \%)$, in the age group from 18 to 25 years old.

Considering the time of the accident, 79 (46.5\%) happened in the afternoon, and predominantly in April and May.

It is worth highlighting that 133 (78.2\%) exposures were percutaneous. In 81 (47.5\%) cases, the causing object was a hollow or suture needle and, in $103(60.6 \%)$ cases, the affected region was their fingers. In $114(67.1 \%)$ cases, there was no information about the use of individual protection equipment; only $40(23.5 \%)$ cases contained records of this equipment being used, whereas six (3.5\%) students stated that they were not using any kind of individual protection equipment at the moment of the accident.

The source patient was identified in 144 accidents $(84.7 \%)$; in $16(9.4 \%)$ cases this identification was not possible; eight accidents (4.7\%) involved material from a non-identified source and two did not have this information.

Out of 170 identified accidents, in 127 (74.7\%) cases, the subject mentioned having received three doses of the vaccine, in $20(11.8 \%)$ two doses, in 08 $(4.7 \%)$ one dose, $03(1.8 \%)$ four doses, 01 (0.6\%) mentioned five doses, $01(0.6 \%)$ could not tell the number of doses. In $04(2.3 \%)$ cases, there was no such information and, in $06(3.5 \%)$ cases, no dose had been received.

Regarding their attitude after the exposure, 125 students $(73.5 \%)$ sought healthcare a few hours after the accident, and only $31(18.2 \%)$ did it immediately, that is, within two hours after the accident, as recommended for this kind of exposure ${ }^{(9)}$. 
In 14 cases $(8.2 \%)$, there was no information about this period of time. In 111 cases (65.3\%), no procedure was followed because the source patient was negative, Zidovudine (AZT) and Lamivudine (3TC) were recommended in $43(25.3 \%)$ cases, AZT, 3TC and Nelfinavir in $15(8.8 \%)$, and the indicated medications were 3TC, Tenofovir, Efavirenz and Atazanavir in only one case $(0.6 \%)$, because the source patient used these anti-retroviral substances.

Considering hepatitis B, in 130 (76.5\%) cases no medical procedure was necessary; in 11 (6.5\%) cases, it was recommended to complete their immunization process; $10(5.9 \%)$ were sent to begin immunization, $10(5.9 \%)$ waited for the exam to start the procedure, eight $(4.7 \%)$ had to reinforce their immunization, and one $(0.6 \%)$ did not have any information about the procedure followed.

\section{DISCUSSION}

Nursing has been appointed as the professional category that is worst-affected by accidents involving biological material(11-12). Nevertheless, in the present study, the analysis of exposure records among healthcare students shows that most accidents, $83(48.8 \%)$, happened to Dentistry students.

Literature shows a high frequency of occupational exposure to biological fluids among dentists, in which the most common is percutaneous exposure ${ }^{(13)}$.

A recent study emphasizes the need for undergraduate Dentistry students to comply with standard precaution recommendations and follow the hospital infection control and prevention guidelines in their clinical activities ${ }^{(14)}$. A similar result was found in a study ${ }^{(13)}$ developed with dentists.

In the study of accidents with biological material among undergraduate Nursing students from a public university in the state of São Paulo ${ }^{(14)}$, it was shown that these students perform their scientifictechnical learning by developing their skills while working with patients and handling piercing-cutting materials, as well as body fluids, which frequently exposes them to the same risks as Nursing professionals.

Regarding the risk of acquiring HBV, the latter may be reduced through pre-exposure prevention measures, with immunization against hepatitis $B$. The vaccine's effectiveness ranges from 90 to $95 \%$, and it is considered one of the most important prevention measures against this virus. Besides, it is indicated before the admission of the healthcare professional or undergraduate student.

A study ${ }^{(15)}$, analyzing the occurrence of accidents with biological material among people from hospital supporting services, identified that $35.4 \%$ of the workers had not received any dose of the vaccine against hepatitis B. Thus, compliance with immunization can also be considered a challenge for professionals who work at the Infection Control Services and Occupational Safety and Medicine Services.

These are distressing aspects, since records about the incidence and prevalence of hepatitis B in Brazil $^{(16)}$ are high and all students were supposed to have been properly vaccinated. Around the world, prevalence rates of $\mathrm{HBV}$ carriers vary from $0.1 \%$ to over $30 \%$, like in Asian countries. The prevalence is high in Brazil, and it is estimated that at least $15 \%$ of the population in general has already been exposed to HBV. The Northern region of Brazil concentrates the highest number of carriers. The worldwide population of HBV chronic carriers is estimated at 450 million people, of which two million are concentrated in $\mathrm{Brazil}^{(17)}$

An analysis of the association between immunization and the positive anti-HBs serology confirmed $86.4 \%$ of immunized people, and immunization among health professionals decreased as age advanced, and also among men. Several studies point out yhe excellent effectiveness of immunization against hepatitis $\mathrm{B}^{(17-18)}$.

Regarding students, they start taking the courses they choose without having any previous knowledge about exposure to biological material and immunization. It is the responsibility of the institutions to provide specific information as soon as the students start these undergraduate courses.

Avoiding occupational exposure is the safest way to prevent the transmission of HBV, HVC and HIV infection. Immunization against hepatitis $B$ and appropriate post-exposure healthcare are essential in an occupational accident prevention program. However, it was observed that many students did not comply with the recommendations related to postexposure care.

It is known that, in cases of accidents involving source patients who are HIV carriers, 
chemoprophylaxis with antiretroviral must be initiated as soon as possible, especially within the first two hours after the accident, since its efficacy is reduced when initiated between 24 and 48 hours after the exposure ${ }^{(9)}$. Antiretroviral therapy has been effective in occupational infection prevention; however, it requires full compliance, and in several cases the professional stops taking the medication due to its adverse effects.

In Brazil, a study with 37 employees of a university hospital who were submitted to chemoprophylaxis, with four weeks of antiretroviral medication, found that $86.5 \%$ of them presented adverse clinical or laboratory events. The medication had to be interrupted in two cases and the therapeutic scheme was substituted in six. The health care provided through a cellular telephone was considered positive for an early identification of adverse events $^{(19)}$.

Although standard precautions are recognized as an important prevention strategy, a study(20) indicates important differences between undergraduate Nursing and Medicine students who had been submitted to specific education programs. It points out that students who participated in an educational program presented higher rates of behavior and knowledge, reinforcing the idea that investments in this area should be encouraged.

Another strategy that has been effective is the use of safety devices, which can reduce the occurrence of percutaneous injuries among health professionals.

The occupational acquisition of HIV, HBV and HVC by healthcare workers is a reality, and its prevention, through the adoption of safety behaviors, should be a constant goal for those who work in the healthcare area. It is observed that students have also been exposed to similar risks in their professional

\section{REFERENCES}

1. Needlestick Transmission of HTLV-III from a patient infected in Africa./ Editorial/ Lancet 1984; 2:1376-7.

2. Ippolito G, Puro V, Heptonstall J, Jagger J, De Carli G, Petrosillo N. Occupational Human Immunodeficiency Virus: worldwide cases through September 1997. Clin Infect Dis 1999; 28:365-83.

3. Do AN, Ciesielski CA, Metler RP, Hammett TA, Li J, Fleming PL. Occupational acquired human immunodeficiency virus (HIV) infection: national case surveillance data during 20 years of the HIV epidemic in the United States Infect Control Hosp Epidemiol 2003; 24(2):86-96. category, which shows the need for specific studies in each area.

\section{FINAL CONSIDERATIONS}

The authors believe that it is essential to implement systemized programs to discuss biosafety in all sectors where undergraduate healthcare students work, which should comprehend effective strategies for accident prevention and occupational risk reduction, mainly in cases of exposure to biological material. Besides, periodic surveillance is needed and notification should be encouraged as other important tools to guide the elaboration of prevention measures and consequently, reduce the risks of accidents.

Undergraduate healthcare students are inserted in activities related to their future professional category and while learning, expose themselves to biological risks. Biosafety measures and safety behaviors should be adopted as early as the first semesters of the undergraduate courses; therefore, undergraduate courses should promote the awareness of safe practices in the work environment, thus contributing to the development of healthcare professionals who are more involved in the prevention of exposure to biological material.

Biosafety is unquestionably important in the professional training of undergraduate healthcare students. Therefore, it must be addressed early in the undergraduate courses or even in technical courses, because the admission of professionals who are more aware of accident prevention and safe behaviors will directly interfere in the current scenario of occupational accidents, who will not only protect their own health, but also that of the clients under their responsibility.

4. Santos NJS, Monteiro ALC, Ruiz EAC. The first case of AIDS due to occupational exposure in Brazil. Braz J Infect Dis 2002; 6(3):140-1.

5. Rapparini C. Occupational HIV infection among health care workers exposed to blood and body fluids in Brazil. Am J Infect Control 2006; 34(4):237-40.

6. Ministério da Saúde (BR). Exposição a materiais biológicos. Brasília:MS; 2006

7. Garner JS. Guideline for isolation precautions in hospitals. Infect Control Hosp Epidemiol 1996; 17(1): 54-80.

8. Ministério da Saúde (BR). Hepatites virais: o Brasil está atento. Brasília: MS; 2005. 
9. Centers for Disease Control and Prevention - CDC - Update US: Public health service guidelines for management of occupational exposures to HBV, HCV and HIV and recommendations for postexposure prophylaxis. MMWR 2001; $50: 1-52$.

10. Centro de Referência e Treinamento em Doenças Sexualmente Transmissíveis (SP). SINABIO acidentes biológicos: mudanças em vigilância, assistência e prevenção. São Paulo; 2007.

11. Marziale MHP, Nishimura KYN, Ferreira MM. Riscos de contaminação ocasionados por acidentes de trabalho com material perfurocortante entre trabalhadores da enfermagem. Rev Latino-am Enfermagem 2004; 12(1): 36-42.

12. Canini SRMS, Gir E, Hayashida M, Machado AA. Acidentes perfurocortantes entre trabalhadores de enfermagem de um hospital universitário do interior paulista. Rev Latino-am Enfermagem 2002; 10(2):172-8.

13. Bellíssimo-Rodrigues WT, Bellíssimo-Rodrigues $F$, Machado AA. Occupational exposure to biological fluids among a cohort of Brazilian dentists. Int Dental J 2006; 56(6): 332-7.

14. Reis RK, Gir E, Canini SRMS. Accidents with biological material among undergraduate nursing students in a Public Brazilian University. Braz J Infect Dis 2004 February; 8 (1): $18-24$

15. Canini SRMS, Gir E, Machado AA. Accidents with potentially hazardous biological material among workers in hospital supporting services. Rev Latino-am Enfermagem 2005; 13(4):496-500

16. Ferreira CT, Silveira TR. Hepatites virais: aspectos da epidemiologia e da prevenção. Rev Bras Epidemiol 2004; 7(4): 473-87

17. Ferreira $C T$; Silveira TR. Prevenção das hepatites virais através de imunização. J Pediatr 2006; 82(3): S55-S66.

18. Ciorlia LAS, Zanetta DMT. Hepatitis B in Healthcare Workers: prevalence, vaccination and relation to occupational factors. Brazilian J Infectious 2005; 9(5):384-9.

19. Ferreira $C T$; Silveira TR. Prevenção das hepatites virais através de imunização. J Pediatria 2006; 82(3): S55-S66. 20. Kim KM, Kim MA, Chung YS, Kim N C. Knowledge and performance of the universal precautions by nursing and medical students in Korea. Am J Infect Control 2001; 29:295-300 